\title{
František Nušl, Vice-President of the IAU 1928-1935, and inventor of the circumzenithal telescope
}

\author{
Petra Hyklová and Martin Šolc \\ Astronomical Institute, Charles University of Prague, Faculty of Mathematics and Physics, \\ V Holešovičkách 2, 18000 Prague 8, Czech Republic \\ emails: martin.solc@mf.cuni.cz, petra.hyklova@gmail.com
}

\begin{abstract}
The Czech astronomer František Nušl (1867-1951) was professor of mathematics, practical astronomy and geometrical optics at Prague Charles University. His scientific contribution to astronomy consisted mainly of inventing and constructing of new astronomical and geodetical instruments. Together with his friend Josef Jan Frič, founder of the Ondřejov Observatory, he developed and improved the circumzenithal telescope (1899-1903-1906-1922-1932), a portable instrument with a mercury horizon for determining the geodetic position using the Gauss method of equal altitudes. This instrument won the gold medal at the Exposition Internationale des Arts et Techniques dans la Vie Moderne in Paris in 1937. Nušl, independently of Ernst Öpik, invented the wobbling mirror for determining the velocity of meteors by visual observation, and constructed an unique guiding system for the Ondřejov astrograph etc. The organisational activities of Frantisek Nušl were considerably rich, too: He was one of the founders of the Czech Astronomical Society in 1917, in the years 1922-1948 he served as its president. From 1918 until his retirement in 1937 he was the director of the Ondřejov Observatory, $40 \mathrm{~km}$ south of capital city of Prague, lectured astronomy at the Prague university and held many popular lectures including regular courses in radio broadcasting. František Nušl was member of several commisions of international scientific unions; he organized the 3rd General Assembly of IUGG (International Union of Geodesy and Geophysics) in Prague 1927, and in IAU (International Astronomical Union) he was elected as Vice-President in the years 1928-1935. One can conclude that he was the main person who formed the Czech astronomy in the interwar period.
\end{abstract}

Keywords. Czechoslovak astronomy, interwar period, circumzenithal, František Nušl

\section{Introduction}

Czechoslovakia, established in 1918 as a successor state of the Austria-Hungary empire, was a small country marginal in terms of language with adverse historical and geographical conditions for the development of modern astronomy, but at the same time close to then scientific centre Germany in geographical and linguistic terms, and also the organizational structures of research and universities were similar. The establishment of International Astronomical Union, that was soon opened for new neutral states and narrowed differences between member states, gave Czech astronomers opportunity to participate in decisions on major international projects and to keep up with development of this branch of science. As delegates of the new republic, their activities on the field of international astronomy were intended to promote our cultural and professional advancement. The interwar period brought a major boom in both professional and amateur Czechoslovak astronomy. The political changes in autumn 1918 - dissolution of the Austria-Hungary Empire and establishment of the new Czechoslovak Republic resulted in great changes in working conditions of professional scientists. One of them 


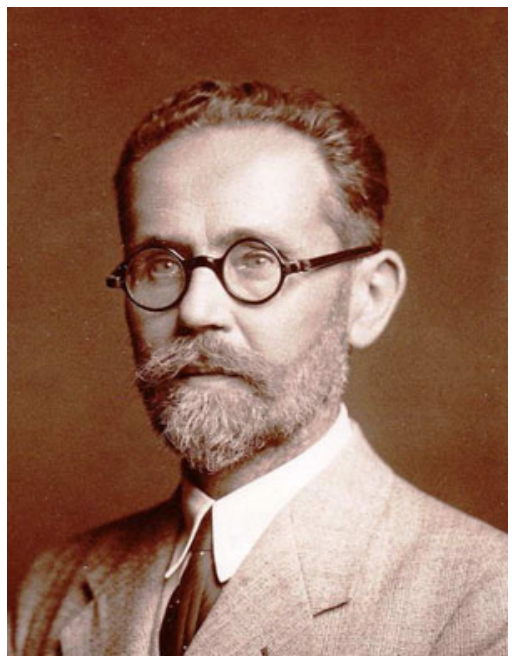

Figure 1. František Nušl in 1930 (Photographic studio Langhans, 1930).

was an increasing participation of Czech scientists on international scientific meetings and organization of international scientific meetings in Czech Republic, which began and revolved around František Nušl.

\section{František Nušl}

František Nušl was born in the family of a whitesmith. In 1879-1888 he attended the Gymnasium (secondary school) in Jindřichův Hradec. At that time he underwent eye surgery for strabismus that was unsuccessful; since then he suffered from blindness on left eye. During his studies at the Gymnasium Nušl had already been interested in physics and astronomy. He made his first simple refractor telescope in his father's workshop, which he successfully used for observation of the 1882 Venus transit. He obtained astronomical almanac for Vienna, observed occultations of stars by the Moon and successfully calculated time deviation due to different longitudes of Vienna and Jindřichův Hradec (Sokol 2003). After he graduated in 1888, he enrolled at the Czech Charles-Ferdinand University. At the beginning of academic year 1889-90 his teacher August Seydler offered him the position of research assistant and accommodation at the Astronomical Institute. In 1893 Nušl passed the teacher qualification examination and in 1894-1909 he taught at secondary schools specialised on natural sciences in Hradec Králové and Prague-Karlín.

At the turn of century Nušl began to work on problem of construction of an instrument for determining geographic coordinates by Gauss method of equal altitudes. This work brought him cooperation and lifelong friendship with Josef Jan Frič (1861-1945), an owner of a small factory producing precision mechanics. They named their new instrument circumzenithal.

Nušl's relocation to Prague in 1901 enabled him also a broader cooperation with Frič in building of his private observatory in Ondřejov village (about $40 \mathrm{~km}$ south of Prague). In 1902 they completed here an observational station for the first model of circumzenithal. After the establishment of the independent Czechoslovak Republic Nušl was appointed the Director of the State Observatory in Prague Clementinum. He maintained a broad scientific correspondence and began to attend international conferences. In 1928 he organized a meeting of the International Union for Geography and Geodesy in 


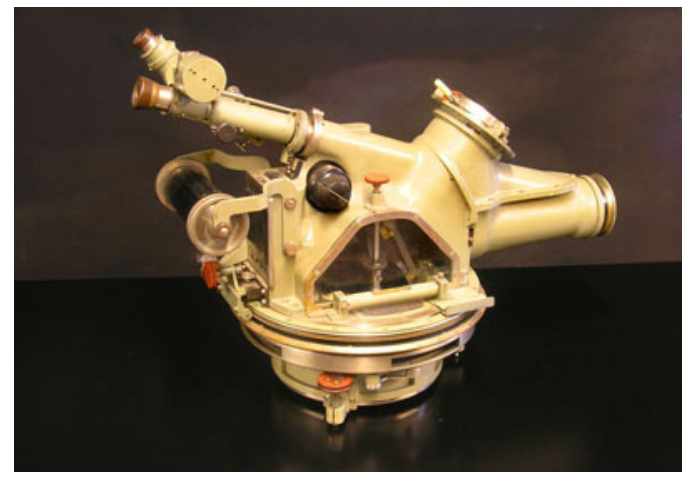

Figure 2. The Nušl-Frič Ondřejov circumzenithal, 1922 (Source: http://wikimedia.org under license Creative Commons CC-BY-SA-2.5).

Prague. Nušl became the central person of the Czech community of professional and amateur astronomers. He participated in establishment of the initially purely amateur Czech Astronomy Society in 1917 and became its chairman in 1922, when the society changed to association of both professional and amateur astronomers. Though Nušl retired in 1938, he was still in the chair of the Czech Astronomical Society until 1948 and continued his work on improving astronomical instruments.

Apart from managing two observatories, Nušl pursued outreach and academic career. In 1905 he habilitated on practical astronomy and geometric optics at the Czech CharlesFerdinand University. In 1908 he was appointed Professor of Mathematics at the Czech Technical University. In 1926 he was appointed Professor of Practical Astronomy. He wrote dozens of articles for Czech science magazines and journals Živa (The Living Nature), Vesmír (The Universe) and Říše hvězd (The Realm of Stars).

Nušl was a talented teacher, and the central person of the Czech astronomy community of the first half of the 20th century. His heritage includes not only precise instruments and inventions, but also many tutees, students and colleagues who continued his work at a high standard.

The minor planet 3425 Nušl, a crater on the dark side of the Moon, the observatory in Jindřichův Hradec and a street in Prague are named after him. The Czech Astronomical Society awarded the Nušl Prize in 1938-1949 and has been awarding it since 1999.

\section{Josef Jan Frič}

Born in Paris in 1861, the Czech entrepreneur and amateur astronomer Josef Alexander Frič was the first son of the Czech patriot, writer, poet, journalist and radical revolutionary Josef Václav Frič.

Josef and his younger brother Jan Ludvík Frič (1863-1897) established their company Josef and Jan Frič - precision mechanics workshop in 1883, that produced quality optical instruments for food-processing industry (polarimeters) and geodesy (theodolites). Josef and Jan planned to build a private astronomical observatory. In 1897, after Jan's unexpected death Josef began to use both names Josef and Jan and commemorated his heritage on every suitable occasion. Josef Jan purchased the land on a hill near Ondřejov, started to build the Observatory of Frič brothers and appointed František Nušl its director.

Though the observatory was private, many professional astronomers worked there. In 1928 Frič donated the observatory to the Czechoslovak Republic by the occasion of the tenth anniversary of its independence. The observatory was managed by the Charles University until establishment of Czechoslovak Academy of Science in 1953. 


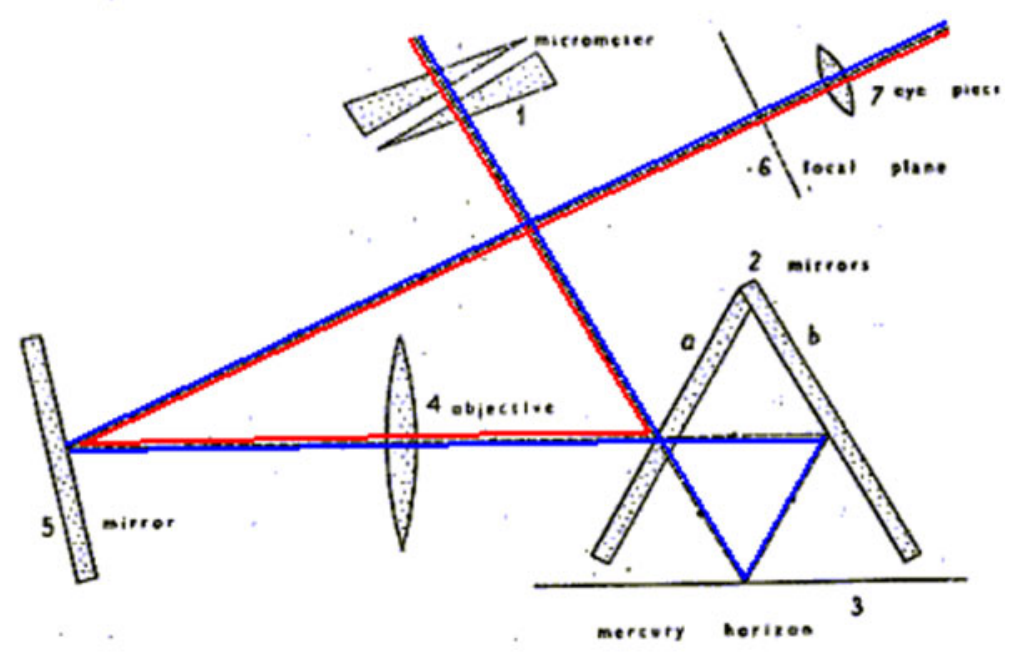

Figure 3. Schema of Nušl-Frič circumzenithal (Source: http://oko.pecny.cz/cirkum.html).

In 1928 Frič was awarded the title doctor honoris causa by the Czech Technical University. The minor planet 7849 Janjosefrič is named after him.

\section{The circumzenithal}

At the end of the 19th century František Nušl began to think about improving the determinination of geographic coordinates using the Gauss method of equal altitudes. The basic element of his instrument became a simple mercury horizon which replaced the function of the expensive precise levels. The light from a star splits into two beams, from which one reaches the eyepiece after 2 reflections on solid mirrors and the other after 3 reflections - two on solid mirrors and one on the mercury horizon. Two images of the star move in the field of view in opposite directions and if they coincide, the star reaches the zenith distance which is given by the angle of two mirrors which are placed like a roof above the mercury horizon (Fig. 3). The observer registers the time of the coincidence. The prototype was made in 1899. Nušl moved to Prague in 1901 and began to work on further refinement and construction of the instrument together with J.J. Frič. They finished the first functional model of Nušl-Frič circumzenithal in 1901, described in Frič \& Nušl (1902).

The final version of the instrument was fabricated in 1922 (Nušl 1922). Its main characteristics were: focus $690 \mathrm{~mm}$, the angle between the mirrors $50^{\circ}$, weight $12 \mathrm{~kg}$, and it was possible to transport the instrument in a backpack. To eliminate the observer error, Nušl constructed an impersonal micrometer with his original invention: mechanic regulator with string attached to the sprocket. In 1950 the circumzenithal was equipped with Buchar impersonal micrometre, which was in 1962 replaced by the Baueršíma-Šurán̆ micrometre of a new construction. Nušl presented the circumzenithal at General Assembly of the International Union for Geodesy and Geophysics in Madrid in 1925. The concept of the instrument raised such an interest that it was requested to demonstrate its function. The Czechoslovak delegate Professor Jaroslav Pantoflíček (1892-1950) hurried back to Prague and brought the circumzenithal to the Madrid assembly. The circumzenithal was also exhibited at the Paris observatory, where Czechoslovak delegates made a stopover on their way back (Nušl 1925).

In 1937 Nušl-Frič presented the circumzenithal at the Exposition Internationale des Arts et Techniques dans la Vie Moderne in Paris in 1937, it acquired a golden medal. In years 1924-47 the circumzenithal was used for determining coordinates of geodetic 


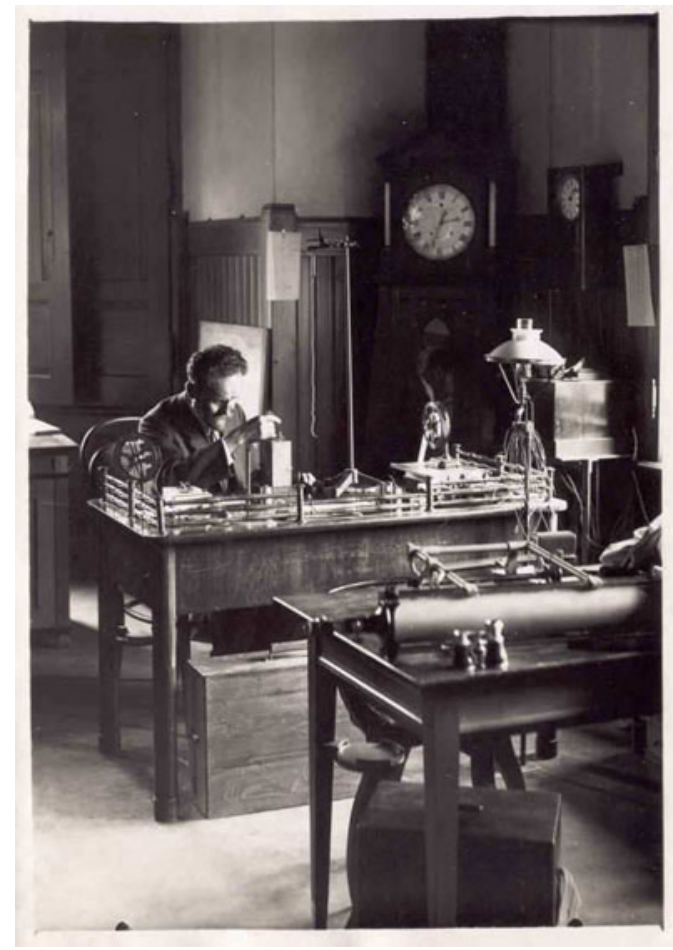

Figure 4. František Nušl in his workshop at Ondřejov observatory (Source: Archive of the Astronomical Institute of the Czech Academy of Sciences).

points in Czechoslovak astronomical-geodetic network. In 1962-69, the measurements at the Geodetic observatory Pecný (Ondřejov) were carried out for the Bureau International de l'Heure (Paris). The instrument accuracy reached $1.5 \mathrm{~m}$ and was comparable to the Danjon astrolabe which became more popular and spread in other countries. In 1967 the Research Institute of Geodesy, Topography and Cartography developed a new model of circumzenithal. These instruments were later used for determination of latitute variations and time corrections of several observatories around the world - in the USA, Eastern Germany, Western Berlin, Sweden, Bulgaria, Nepal, and North Korea in 1970-1990. Some of them were equipped with micrometer motor gearing and motor azimuthal gearing. In 1977 another two instruments were developed by Research Institute of Geodesy, Topography and Cartography - circumzenithals 50/500 for field astronomical work and $100 / 1000$ for station observatories.

Some other instruments invented and constructed by Nušl are displayed in the Ondřejov Museum of astronomical instruments: radiozenithal and diazenithal, two instruments based on mercury horizon and two mirror planes (Frič \& Nušl 1904), and an unique guiding system for the Ondřejov astrograph. In August 1926, Nušl constructed (independently of Ernst Öpik) a wobbling mirror for determining the velocity of meteors by visual observation, the conical motion of the mirror made all the meteor trails cycloidal independently on the direction of the meteor.

\section{František Nušl and the IAU}

In the interwar period, František Nušl influenced not only the community of Czech astronomers but also participated actively in international scientific meetings (Hyklová 2018). He was the first and only Czechoslovak delegate at the first IAU General Assembly in Rome 1922, at which Czechoslovak Republic entered the IAU. 
Nušl was elected member of three commissions and entered the Financial Committee for 1922-25. Altogether, he attended the general assemblies in Rome 1922, Cambridge 1925, Leiden 1928, and Paris 1935.

In 1928 Nušl was elected Vice-President of the IAU and in 1932 he was reelected, though not being present at the general assembly in Cambridge (US).The 1932 general assembly had a low attendance due to economic recession and unfavourable price of US dollars (Chant 1932).

Since 1922 Nušl was member of three commission: Commission de l'Astronomie méridienne (Commission 8) in 1922-28, Commission des Instruments Astronomiques (Commission 9) in 1922-35 and Commission des Longitudes par Télégraphie sans Fil (Commission 18) in 1922-38 (Fowler 1922, 1925; Stratton 1929, 1933, 1936; Oort 1939). Nušl retired in 1938 and did not attend the Stockholm general assembly.

\section{Summary}

Participation in general assemblies of the post-WW1 scientific unions was a new experience for leading Czech astronomers. Among the Czech astronomical community, František Nušl was the first to participate in general assemblies of the International Astronomical Union and the International Union for Geodesy and Geophysics. He actively relegated experiences from work in these organisations to his colleagues and to the new generation of young Czech astronomers, who later became internationally successful as well.

\section{Acknowledgement}

This paper was prepared under support of the Grant Agency of Charles University (project no. 1152216) and at the final stage also of Grant Agency of the Czech Republic (project No. 19-20678S).

\section{References}

Chant, C. A., 1932, Journal of the Royal Astronomical Society of Canada, 26, 377

Fowler, F. J. M. (ed.) 1925, Transactions of the IAU Vol. II. Second general assembly held at Cambridge July 14 to July 2, 1925. London: Imperial College Bookstall

Fowler, F. J. M. (ed.) 1922, Transactions of the IAU Vol. I. First general assembly held at Rome, Italy, May 2 to May 10, 1922. London: Imperial College Bookstall

Frič, J. J., \& Nušl, F., 1902, Note sur deux appareils sans niveaux pour la determination de l'heure et de la latitude. Paris, Gaulthies-Villars

Frič, J. J., \& Nušl, F., 1904, Astronomische Nachrichten 166, 15, 225-228

Hyklová 2018, in Science overcoming borders, Dvořáčková, Franc (eds.), in press

Nušl, F. 1922, Řiše hvězd, 3, 85-89

Nušl, F. 1925, Říše hvězd, 6, 10-17

Oort, J. H. (ed.) 1939, Transactions of the IAU Vol. VI. Sixth General Assembly held at Stockholm August 3 to August 10, 1938. Cambridge: University Press

Sokol, J. M., Grandpa Nušl (in Czech) 2003, Kosmické rozhledy, 1

Stratton, F. J. M. (ed.) 1929, Transactions of the IAU Vol. III. Third general assembly held at Leiden July 5 to July 13, 1928. Cambridge: University Press

Stratton, F. J. M. (ed.) 1933, Transactions of the IAU Vol. IV. Fourth general assembly held at Cambridge, Massachusetts September 2 to September 9, 1932. Cambridge: University Press

Stratton, F. J. M. (ed.) 1936, Transactions of the IAU Vol. V. Fifth general assembly held at Paris July 10 to July 17, 1935. Cambridge: University Press 